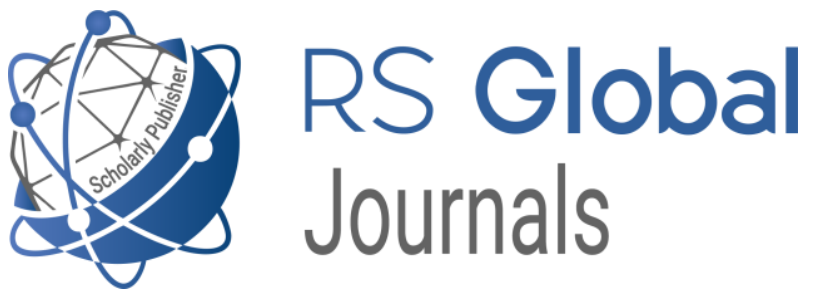

Scholarly Publisher

RS Global Sp. z O.O.

ISNI: 0000000484952390

Dolna 17, Warsaw, Poland 00-773

Tel: +48226022703

Email: editorial_office@rsglobal.pl

JOURNAL International Journal of Innovative Technologies in Social Science

p-ISSN 2544-9338

e-ISSN 2544-9435

PUBLISHER RS Global Sp. z O.O., Poland

ARTICLE TITLE ARMENIAN ASHUGH ART OF THE 18th CENTURY

AUTHOR(S) Asatryan A. H., Harutyunyan H. H., Khachatryan D. K.

Asatryan A. H., Harutyunyan H. H., Khachatryan D. K. (2021)

ARTICLE INFO Armenian Ashugh Art of the 18th Century. International Journal of Innovative Technologies in Social Science. 4(32). doi:

10.31435/rsglobal_ijitss/30122021/7732

DOI

https://doi.org/10.31435/rsglobal_ijitss/30122021/7732

RECEIVED

20 October 2021

ACCEPTED

13 December 2021

PUBLISHED

17 December 2021

LICENSE

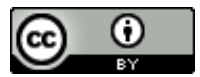

This work is licensed under a Creative Commons Attribution

4.0 International License.

(C) The author(s) 2021. This publication is an open access article. 


\title{
ARMENIAN ASHUGH ART OF THE 18th CENTURY
}

\author{
Asatryan A. H., Researcher, Shirak Centre for Armenian Studies of NAS RA, Gyumri, Republic of \\ Armenia \\ Harutyunyan H. H., PhD in Art, Shirak Centre for Armenian Studies of NAS RA, Gyumri, Republic of \\ Armenia \\ Khachatryan D. K., Researcher, Shirak Centre for Armenian Studies of NAS RA, Gyumri, Republic of \\ Armenia
}

DOI: https://doi.org/10.31435/rsglobal_ijitss/30122021/7732

\section{ARTICLE INFO}

Received 20 October 2021

Accepted 13 December 2021

Published 17 December 2021

\section{KEYWORDS}

Tiflis, New Julfa, Sayat-Nova, ashugh, traditional music, Song, Armenian compositions multiethnic.

\begin{abstract}
Ashugh art is a pan-Eastern tradition that stems from the cultural origins of the peoples of the Middle East and the Caucasus. The stages of formation and development of Armenian troubadour art are still of great interest today. It should be noted that even today new facts and materials are discovered that need to be observed and studied. In the XVIII century we should already talk about the activities of the Armenian troubadour centers. In this article we have touched upon the important features of the centers established by the Armenian ashughs in Tiflis and New Julfa.
\end{abstract}

Citation: Asatryan A. H., Harutyunyan H. H., Khachatryan D. K. (2021) Armenian Ashugh Art of the 18th Century. International Journal of Innovative Technologies in Social Science. 4(32). doi: 10.31435/rsglobal_ijitss/30122021/7732

Copyright: (C) 2021 Asatryan A. H., Harutyunyan H. H., Khachatryan D. K. This is an open-access article distributed under the terms of the Creative Commons Attribution License (CC BY). The use, distribution or reproduction in other forums is permitted, provided the original author(s) or licensor are credited and that the original publication in this journal is cited, in accordance with accepted academic practice. No use, distribution or reproduction is permitted which does not comply with these terms.

The research was carried out financially provided by the ESCS of the Ministry of Education and Science of the Republic of Armenia with the support of 21T-6E197 scientific topic.

Troubadour-ashugh art is a powerful layer in the Armenian musical-theatrical culture, the roots of which go back to the depths of millennia. The artistic function of the troubadour, according to the classical perception, is to be a poet, a musician, a composer, a comprehensive artist who blends the elements of literature, music, dance and theater.

Armenia is a country with a high troubadour culture. Located at the crossroads of East-West, Armenian specialized music has included, on the one hand, the monodic emotional melody of the East, and, on the other hand, a number of other elements of the melodic structure of the melody.

The troubadour songs were the most popular and popular in the music-making art of the Oriental tradition, which originated in the artisanal areas of the urban population. The gems of Armenian troubadour art were sung and passed down orally from generation to generation.

The art of troubadour contains several elements: lyric poetry, music, authorial performance, accompaniment, so it is complex in its kind. In order to become an ashugh, one had to pass professional training with a "master ashugh", compose melodies, poems according to the ashugh grammatical rules, memorize the ashugh classical patterns, improve special typical melodies, participate in ashugh competitions, enter the parliament, be a poet, reciter, musician composer, instrumentalist, have high mastery of performance, baptized in the patron saint church of ashughs in St. Karapet monastery of Mush.

The poetry of folk singers-poets originated in the 16th century. Having been orally before, he was closely related to folklore. Armenian troubadours appeared in the middle of the 16th century, but troubadour poetry became widespread and known in the Armenian reality only in the next century. Due to 
historical and political circumstances, troubadour poetry originated not in Armenia itself, but in the Armenian colonies of New Julfa, Tiflis, Astrakhan, K. In Constantinople l. etc. In the 17th-18th centuries, the ashughs of New Julfa (Ezaz, Ghra Arzuni, Bader oghli Ghazar, Amir oghli, Gul Harutyun Salmastatsi, etc.) founded the Iranian-Armenian ashugh school, the first in the history of Armenian culture.

The socio-political and cultural awakening that began in the Armenian reality in the first quarter of the 17th century contributed to the development of fiction. Thanks to the newly created printing press (1512), the rich medieval Armenian written heritage was revived. In the 17th and 18th centuries, the predominant literary genre was lyric poetry [1].

It is difficult to judge how our poets sang and performed. There are separate references to the 19th century, but from the 16th to the 17th centuries, when the art of troubadour had already begun to take shape, troubadours within the syncretic genre showed their acting talent during troubadour competitions. And this was especially evident in the performance of troubadour romances throughout the East, where the troubadour had such mimicry, gestures, and mastered such a theatrical system that even an audience that did not know the language admired and applauded. There are many references to how these romances were told, interrupted at the most dramatic moment, so that the next day the people would come with great interest and listen to the continuation. Such a theatrical performance by one person has been going on for days. The meaning of the mimosa's pantomime may have been more important in the time of the cowboy art, but some elements were nevertheless transferred to the art of asceticism.

In the 17th-18th centuries, the Armenian ashugh, poetry reached an unprecedented height thanks to Sayat-Nova. With the power of powerful talent, stressed personality, agitated love songs and high humanitarian ideas, Sayat-Nova came out of the ashugh, beyond the borders of rhetoric, to stand next to the greatest medieval poets. Together with Naghash Hovnatan he concluded the medieval Armenian lyric poetry.

The Armenian presence in Tbilissi (Georgia) has a rich past. The Armenian element has been an active, constructive and creative part of the city of Tbilissi for centuries. It is no coincidence that today the local Armenians are proud. They emphasize that they are a state-building nation in Georgia.

Armenian nomadic ashughs composed their songs in the colloquial language of the people, often in Turkish, Persian, Georgian, etc. The most famous ashughs created in several languages are Sayat-Nova, Shamchi Melko, Hartun Oghli and Mahtes Siruni. Love songs are predominant in troubadour poetry. The ashughs responded to the historical and political events that worried the people. In satirical poetry, satirical songs occupy a certain place, which include rich biographical materials and have cognitive value.

"Sayat-Nova was an 18th century Georgian/Armenian poet, musician and sometime royal court diplomat. He entertained courtiers for a while before falling out of favour and then lived the life of the wandering ashugh. Later in his life he became an apostolic priest in Armenia which was, at that time, a deeply religious country.

Records suggest that he was born Harutyun Sayatyan in June 1712, in the Georgian city of Tbilisi, which was also the birthplace of his mother Sara. His father was called Karapet and may have had Syrian or Turkish roots though this is not certain. He adopted the nickname Sayat-Nova and grew up writing and speaking the language of his mother and was soon exhibiting great skills as a writer, singer and musician. He learned to play a variety of stringed instruments such as the Persian kamancheh, the Georgian chonghur and the Turkish tambur. He was also a talented writer of music and eventually wrote songs and poems in a number of different languages including Armenian.

His abilities were recognised by the ruler of Georgia, Erekle II, and he entertained courtiers daily. He was also granted diplomatic status and it is believed that his skills in that line were utilised during the formation of an alliance between the countries of Shirvan, Armenia and Georgia against the threat posed by the much larger Persian Empire. Sayat-Nova was, though, more artist than politician and he let his heart rule his head when forging an alliance of his own. He fell in love with the sister of King Erekle and was summarily banished from court" [8].

Tiflis was a multicultural center in Transcaucasia, where different nations worked in different languages, but these are not certificates of the ideas of internationalism and friendship attributed to Sayat-Nova. In general, in the Middle Ages, especially in the field of troubadour art, the criterion of mastery was the possession of traditional, canonical knowledge, the excitement of the audience consisting of different ethnic elements, their communication with art. This was a music-creating and traditional environment, which was close to Sayat-Nova, he created in the languages of those peoples, 
made their art understandable to them. "The troubadour does not close in the monastery, writes hymns and hymns. If there is no audience, there is no troubadour music, so the main way to perform was the troubadour competition. The ashughs had to go out to the square or the square, compete, lu the people or the elite had to appreciate their art. Personal thoughts and reflections were, of course, typical of troubadour art, but it was a broad public art with its own ritual and knowledge, which was familiar to the people, satisfying their artistic taste. It was also a syncretic art, if our philologists say that he is a genius poet, but a gifted musician, I do not agree with that, because the word ashugh implies a syncretic work, equally poetic, instrumentalist, singer, musician, suddenly one of those components. The absence of someone would not have brought to the troubadour the fame and respect that Sayat-Nova received as a musician-sudden, a poet, an esthetician. This is the title and nature of the troubadour" [6].

Absolutely right Xi Yang: Focusing on these neglected issues will enable a richer understanding of Sayat-Nova's place in the history of the ashugh/aşı/kş̧ı tradition as well as his relation to the elevated poetic traditions in South Caucasia, the Armenian aufs' contribution within the broader matrix of the early modern Turkic aşık/aşıq tradition, and the evolution of a distinct ašuf tradition in the Armenian language. At the same time, exploring his posthumous adoption as a cultural icon will provide insight into the history of scholarship and of mass culture both in South Caucasia and for Armenians worldwide [7]. "That Sayat'-Nova is rarely contextualized in a bardic matrix also has further implications. In many monographs, he is treated more as a well-educated, elite poet, whose works are written in an elevated literary language for an elite readership, rather than as an ašuf composing in an idiom closer to the spoken language for oral performance to a wider audience. This has inevitably led to numerous comparisons and parallels drawn between Sayat-Nova and famous poets, from East to West, often based on superficial external similarities in images or tropes rather than an in-depth analysis of the given authors and their ambience. Similarly, Dowsett's comparisons of Sayat'-Nova with Provençal troubadours of the thirteenth to fourteenth centuries6 do not take into consideration the major differences in period, situation, and conventions between these two traditions. Even fewer comparisons have been made between Sayat'-Nova and compararble Turkic aşık/aşıqs of the sixteenth to eighteenth centuries, or internal comparison of Sayat'-Nova's different styles in different languages (Armenian, Azeri, Georgian)" [7, p. 4].

A large number of Armenians oppressed and deported by Turkey's wars between Persia and Persia, appearing in Persia in the early 17 th century, not only managed to preserve their identity, but in a short period of time became one of the vital pulses of the country's economy and culture. In this context, the troubadour art of New Julfa was formed, becoming the first school of Armenian troubadour literature.

Each of the ashughs of New Julfa has the opportunity to express his personality. Gul Egaz, Bagher Oghli, Amir Oghli, Gul Hovhannes, Keshish Oghli Jughayetsi and Hartun Oghli stand out with love poems, each of which has its own handwriting, as each speaks about his personal emotions and feelings." In the love works of the troubadours of New Julfa, the image and function of the troubadour is gradually outlined, which not only fully corresponds to the classical perception of the term "troubadour", that is, "loving singer", but also gives the opportunity to see the same troubadour as an author. at the same time a hero of his own performance. Later, the troubadour became a self-sufficient artist with his role in society, his contribution to poetry. The New Julfa troubadour school became a copycat and importer of the Armenian's poetry and troubadour deposits into the Armenian reality, nevertheless, they served as a basis on which the troubadours created original images, gave the molds an individual tone, spiced with Armenian folk psychology and thinking. This is how the New Julfa troubadour school is valued in the development of Armenian troubadour literature. According to the regularity of the troubadour literature, the theme of love and love poems are key in the works of the troubadours of New Julfa. The woman, drawn through Arela's colorful descriptions and love illustrations, comes to life over time, gaining character and voice, eventually becoming an active actor" [6].

As Sose B. Poghosyan rightly remarked, as troubadours' literature assumes, the literary conception of love here is quite crucial. Ashughs' characters and functions come to confirm the real perception of "Ashugh" term, which is amorous singer. The latter is determined as a multilateral artist, who is both the author and the performer of his songs. Woman is worshiped as the object of love. The act of loving was in itself ennobling and refining one, the means to the fullest expression of which were potentially fine and elevated in human nature. Woman gradually gets revived and by gaining voice and character, becomes the part in that love game. 90 A special notice has been paid to the 
"Ashugh" word etymology. Its manifestations and functional meaning in different in nations' languages that had examined Ashughs' heritage [6].

Conclusions. Armenian ashugh's centers were formed as a result of historically justified public demands. And in Tiflis and New Julfa, these centers were represented by the activities of famous ashughs. They were gifted poetic musicians who spoke several languages, knew acceptable melodies and instrumental instruments. The art of these troubadours is considered classical due to the harmonious unity and originality of many important components.

\section{REFERENCES}

1. Hay ashughner. 17-18-rd dd., Ye., «Haykakan SSR Gitutyunneri akademiayi hrat», 1961

2. Yeremyan A.G., Ashugh Hartun Oghli, Nor Jugha, «Tparan Amenaprkchyan Vanki» hrat., 1920

3. Levonyan G. J., Ashughnery yev nranc arvesty, Ye., «Haypethrat», 1944

4. Levonyan G. J., Levonyan, Yerker, Ye., «Haypethrat», 1963

5. Bakhcinyan H. G., 17- 18- rd dareri hay grakanutyuny, Ye., «Luys» hrat., 1999

6. Retrieved from https://vemjournal.org/wp-content/uploads/2020/07/05-

\%D4\%B3\%D6\%80\%D5\%A1\%D5\%AF\%D5\%A1\%D5\%B6\%D5\%A1\%D5\%A3\%D5\%AB\%D5\%BF\%D5 \%B8\%D6\%82\%D5\%A9\%D5\%B5\%D5\%B8\%D6\%82\%D5\%B6-2018-2.pdf

7. Xi Yang. Sayat-Nova: Within the Near Eastern bardic tradition and posthumous A dissertation submitted in partial satisfaction of the requirements of the degree Doctor of Philosophy in Near Eastern Languages and Cultures. UNIVERSITY of CALIFORNIA. Los Angele, 2016

8. Retrieved from https://mypoeticside.com/poets/sayat-nova-poems 